
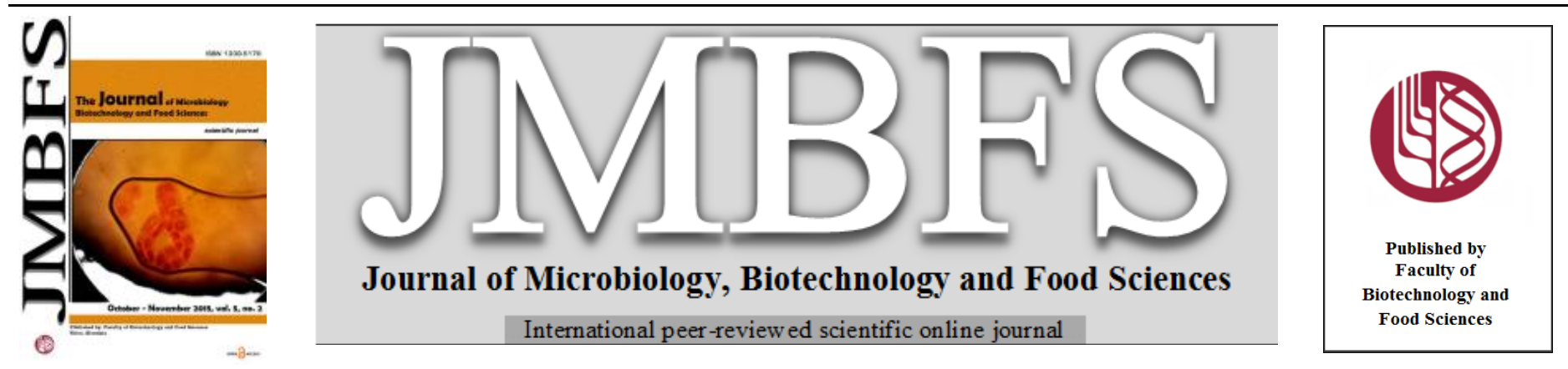

\title{
IMPROVEMENT OF AFRICAN TRADITIONAL SORGHUM BEERS QUALITY AND POTENTIAL APPLICATIONS OF PLANTS EXTRACTS FOR THEIR STABILIZATION: A REVIEW
}

\section{Christian Tétédé Rodrigue KONFO*I, Nicodème Worou CHABI $^{2}$,Edwige DAHOUENONI-AHOUSSI ${ }^{1}$,Martial CAKPO-CHICHI ${ }^{2}$, Mohamed Mansourou SOUMANOU ${ }^{3}$, Dominique Coco Kodjo SOHOUNHLOUE ${ }^{1}$}

\author{
Address(es): \\ ${ }^{1}$ University of Abomey-Calavi, Polytechnic School of Abomey-Calavi, Laboratory of Study and Research in Applied Chemistry, 01 BP 2009 , Cotonou, Benin. \\ ${ }^{2}$ University of Abomey-Calavi, Polytechnic School of Abomey-Calavi, Teaching and Research Laboratory in Food Microbiology.
}

*Corresponding author: konfo01@yahoo.fr

doi: 10.15414/jmbfs.2015.5.2.190-196

\section{ARTICLE INFO}

Received 8. 9. 2014

Revised 21. 7. 2015

Accepted 17. 8. 2015

Published 1. 10. 2015

Review

OPEN 2 ACCESS

\begin{abstract}
In Africa, various kinds of traditional alcoholic beverages commonly named sorghum beers or opaque beers, have been recorded and described. These drinks have a central role in peoples' cultures and play fundamental socioeconomic function. Their brewing involves malting, mashing, souring, straining, boiling and two successive steps of fermentation which occur at ambient conditions. A primary lactic fermentation, or souring stage, confers the souring taste and storage longevity. The alcoholic fermentation is usually initiated by pitching wort with a portion of previous brew. The beverage thus obtained is unstable. Since the African sorghum beers fermentation process is run by uncontrolled inoculation under no standard hygienic conditions, producers have a major problem to make a good beer with a long shelf-life. In other hand, recently the disappearance of many active synthetic substances in foods protection has resulted to a renewed interest in naturally occurring substances. In parallel to these disappearances, the regulatory environment incites strongly to increase the use of alternative methods to chemical control. This review aims to summarize works about African traditional sorghum beers stabilization and potential applications of plants extract for their natural preservatives.
\end{abstract}

\section{INTRODUCTION}

Fermentation is one of the oldest and most economic methods of producing and preserving foods, particularly in tropical countries where the high temperature and humidity, coupled with unsanitary conditions, favor food spoilage (Hounhouigan, 1994).While in developed countries, most fermented food are produced under controlled conditions, in developing countries, such foods are processed under uncontrolled conditions, using village habits and age-old techniques (Nout and Rombouts, 1992). In Africa, various kinds of traditional fermented beverages commonly named sorghum beers or opaque beers have been described. These beers are known as ikagage in Rwanda (Lyumugabe $\boldsymbol{e t}$ al., 2010), pito or burukutu in Nigeria and Ghana (Achi, 2005), dolo in Burkina Faso (Dicko et al., 2006), amgba in Cameroon (Lyumugabe et al., 2010), doro or chibuku in Zimbabwe (Chamuorwa et al., 2002), Merissa in Sudan (Dirar 1978), mtama in Tanzania (Tisekwa 1989), bili bili in Chad (Maoura et al., 2005), kaffir in South Africa (Novellie et al., 1986) and tchakpalo in Ivory Cost, Togo and Benin (Konfo et al., 2012). These drinks have a central role in peoples' cultures and are an important part of the diet for an increasing part of urban population. The present review deals on tchakpalo in Benin. Initially produced in the center of the country, this drink has spread throughout the country and especially in the economic capital where it knows a boom. In its usual production technology, we note the presence of a double fermentation: an alcoholic one which combines natural lactic fermentation. Over time, the conditions of the production have not changed. The drying of germinated sorghum grain is made in natural air, in border of the ways. Moreover, the production process suffers of a crucial lack of measuring instruments and precision, good hygiene practices and wort are inoculated with the yeast from previous fermentation whose hygienic quality is often not guaranteed. The resulting product is alive and unstable and its organoleptic characteristics continue to change, and within $72 \mathrm{~h}$ it becomes too acidic to be consumed. The short shelf-life of this traditional brewing method limits its consumption to within a day of its production and hence its availability is limited to the seasonal availability of the sorghum grain (Osseyi et al., 2011). It is then important to improve production and conservation technology of this product in order to preserve its nutritional and merchantable qualities and to reduce the risk of food intoxination. Microbial activity is a primary mode of deterioration of foods and many microorganisms contributed for the loss of food quality and safety Chemical antimicrobial compounds had been largely used as foods preservatives, but unfortunately their use increases the risk of toxic residues in the products (Tatsadjieu et al., 2009; Yèhouénou et al., 2010a). Plants extracts as antimicrobial agents are recognized as safe natural substances to their user and for the environment and they have been considered at low risk for resistance development by pathogenic microorganisms (Antunes and Cavaco, 2010). This paper aims primarily to summarizing the research results on improvement of African traditional beers processes and collecting information relative to the major components of Cymbopogon citratus, Mentha spicata and Hemizygia bracteosa which provide them potential antimicrobial properties and their capacity in this drinks bio preservation.

\section{ORIGIN, SOCIOECONOMIC ASPECTS AND NUTRITIONAL COMPOSITION OF SORGHUM BEER}

African cereal beers (made from sorghum, millet, maize, etc.) have ancient origins. They may have originated in Egypt or Mesopotamia, where beers were being produced by at least 3,500 BC, and probably much earlier (Briggs $\boldsymbol{e t}$ al. 1981). The first mentions of sorghum or millet beer come from the Arab travellers who, in the 6th and 7th centuries, praised the merits of beer manufactured in the Sahel region, in particular the merissa beer of Sudan (Huetz de Lemps, 2001). The manufacturing of sorghum beers is a tradition preserved by African women brewers and passed down to the next generation. According to Osseyi et al. (2011) in Togo, approximately $60 \%$ of the national production of sorghum is used to produce two kinds of sorghum brew: Tchakpalo and Tchoukoutou. The production and marketing of Sorghum beer remain women's activities from which they derive a substantial income. Tchoukoutou is sold and consumed in special cabarets that are popular bars and places of huge conviviality. Sorghum beer plays a fundamental socioeconomic role in northern Togo where it is abundantly served to maintain an atmosphere of merriment in all celebrations. This beer is also used in religious ceremonies, libations and traditional rituals. Sorghum beer is called the "milk of the hoe" in Africa (amata $y$ 'isuka in the Rwandese language), affording the beer noble qualities (De Lame, 
1995). Sorghum beer is an ancestral beverage widely used in various festivals and African ceremonies such as marriage, praying for rain, communication with ancestors, births, the handing-over of a dowry, circumcision, burial ceremonies, and the popular annual sorghum festival (Kayodé $\boldsymbol{e t}$ al., 2007a; Lyumugabe $\boldsymbol{e}$ al., 2010). In Rwanda or Burundi, dowry handing-over ceremonies start initially with the consumption of traditional sorghum beer. The representatives of the two families greet each other around a clay jug (called an ikibindi) filled with sorghum beer because ikigage beer symbolizes the complementarily of the sexes (De Lame, 1996). Traditional sorghum beer is also consumed after community work or meetings of mutual associations, in order to provide energy. There are mainly consumed by the poorest in society, and contributes significantly to the diet of millions of African people It is very rich in calories. It is also rich in the B-group vitamins including thiamine, folic acid, riboflavin, and nicotinic acid and is high in essential amino acids such as lysine. They contained mineral elements such as calcium, magnesium and iron that were essential for regulating and building the living cells and aid in fighting depression (Kayodé $\boldsymbol{e t}$ al. 2007b).

\section{IMPROVEMENT OF THE MANUFACTURING PROCESSES OF AFRICAN TRADITIONAL SORGHUM}

Malting, mashing, boiling, souring, and fermentation, are the general steps of the beer brewing processes. Several studies have focused on these different stages particularly malting and fermentation.

\section{MALTING OPTIMIZATION}

The sorghum malting process is split into three unit operations: steeping, germination, and drying (Dewar et al 1997; Taylor and Dewar 2000).

Steeping involves immersing the grain in water until it has imbibed sufficient water to initiate the metabolic processes of germination. The steeping period at a given time varies according to the sorghum cultivar. A variation in moisture content of 32.4 to $43.4 \%$ has been observed after steeping 26 sorghum cultivars for 24 h (Kumar et al., 1992). The effect of steeping conditions has been extensively investigated in an attempt to increase sorghum malt amylase activity. Novellie, 1962 reported that steeping time had little effect on the final diastatic power of sorghum malt. A steeping regime, and in particular the use of air-rests and a final warm water $\left(40{ }^{\circ} \mathrm{C}\right)$ steeping period has been shown to enhance sorghum malt quality, including $\beta$-amylase activity (Ezeogu et al., 1995). A later study specifically confirmed the importance of the effect of air-rests on the level of sorghum malt $\beta$-amylase activity (Okungbowa et al., 2002). $0.1 \%$ of $\mathrm{Ca}(\mathrm{OH})_{2}, \mathrm{KOH}$ or $\left.\mathrm{NaOH}\right)$ has been shown to significantly enhance the diastatic activity of sorghum malt especially $\beta$-amylase activity (Okolo et al., 1996; Okungbowa et al., 2002).

Germination induces the synthesis of hydrolytic enzymes, e.g. starch degrading enzymes, and proteases. This operation is recommended between 25 and $30^{\circ} \mathrm{C}$ for the development of optimum amylase and diastatic power in sorghum malt (Novellie 1962; Okafor et al., 1980). The reduction of phytic acid, some flavonoids and proanthocyanidins has been observed during germination (Traoré et al., 2004). The increase of the availability of minerals (iron, zinc, etc.) and essential amino acids (principally Lys, Tyr and Met) upon germination has also been reported (Anglani, 1998).

While germination usually has positive aspects, it is important to note that it increases the content of nitrilosides (cyanogenic glycosides, e.g. dhurrin) of the grain (Ahmed et al., 1996; Traoré et al., 2004). These compounds release cyanide (prussic acid) which may be removed either by heating the flour or removing shoots, roots and the germs, but removing the latter reduced the content in $\alpha$-amylase (Uvere et al., 2000; Traoré et al., 2004). Upon germination, the initially low content of vitamin $C$ is strongly increased (Taur et al., 1984) According to Ballogou et al. (2011), the physico-chemical and sanitary qualities of malts could be improved by controlled drying in shell drier. Sun drying involved an exposure to microorganisms and the high final moisture content of the malt was not interesting for its conservation. The table 1 shows controlled drying effect on the quality of sorghum malts used for the chakpalo Production in Benin.

Table 1. Dried malts microbiological characteristics (Ballogou et al., 2011).

\begin{tabular}{|c|c|c|c|}
\hline \multirow{2}{*}{ Microorganism } & \multicolumn{3}{|c|}{$\log ($ CFU/g) } \\
\hline & Malt 1 (dried malt under the sun) & Malt 2 (dried malt using the drier) & AFNOR Criteria \\
\hline Total Coliforms & $6.3 \pm 0 . .35$ & $3 \pm 0.42$ & 2 \\
\hline Faecal Coliforms & $4.3 \pm 0.7$ & 0 & - \\
\hline Staphylococci & $3.9 \pm 0.14$ & $1 \pm 0.09$ & 0 \\
\hline Sulfito-reducers & $2.32 \pm 0.12$ & $2 \pm 0.25$ & 2 \\
\hline $\begin{array}{l}\text { Anaerobes } \\
\text { Yeasts and Moulds }\end{array}$ & $7.3 \pm 0.42$ & $3.69 \pm 0.26$ & 3 \\
\hline
\end{tabular}

- Absence of criterion

Brewing of sorghum beer (tchakpalo)

The brewing of sorghum beer (tchakpalo) is done in several phases:

$\checkmark \quad$ Crushing, mashing and thinning 1: Malt is crushed and the coarse meal obtained is added a quantity of water and kneaded until a moderately thick paste. This paste is left in the sun for about seven hours before being diluted 'in water ( 2 to 3 liters of water for $1 \mathrm{~kg}$ of grain). The suspension thus obtained is homogenized and then allowed to stand at room temperature $\left(28-29^{\circ} \mathrm{C}\right)$ for eight hours.

$\checkmark \quad$ Cooking 1: The mixture separates into two phases (1 decantate and decantation residue 1$)$. The residue is collected and slurried in a large amount of water ( 3 liters per $1 \mathrm{~kg}$ of grain). The whole is boiled. During 150 minutes at $106^{\circ} \mathrm{C}$.

$\checkmark \quad$ Cooking 2: The cooled mixture is separated into a supernatant liquid (decantate 2) and a solid deposit (settling residue 2). The latter is collected, slurried in water ( 1 to 2 liters. Per $1 \mathrm{~kg}$ of seeds) and cooked to a temperature of $95^{\circ} \mathrm{C}$. This takes about $1 \mathrm{H} 45$ minutes before cooling and filtration. The filtrate obtained is mixed with decantate 2 to obtain initial wort that is sterilized for 5 hours by boiling.

The diagram below shows the tchakpalo production technology. 
Sorghum grain

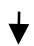

Malting (soaking, germination, drying)

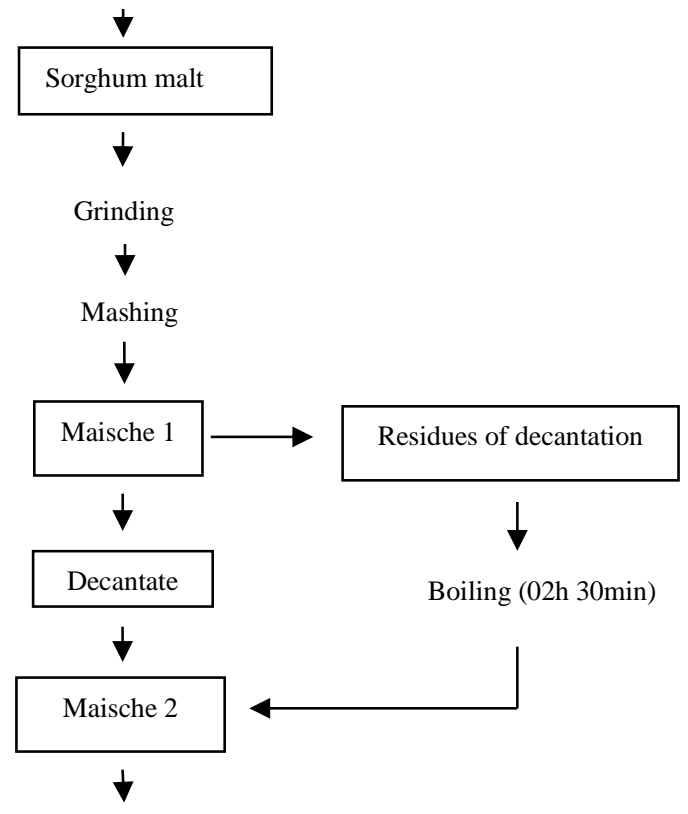

Acidification $(09 \mathrm{H})$

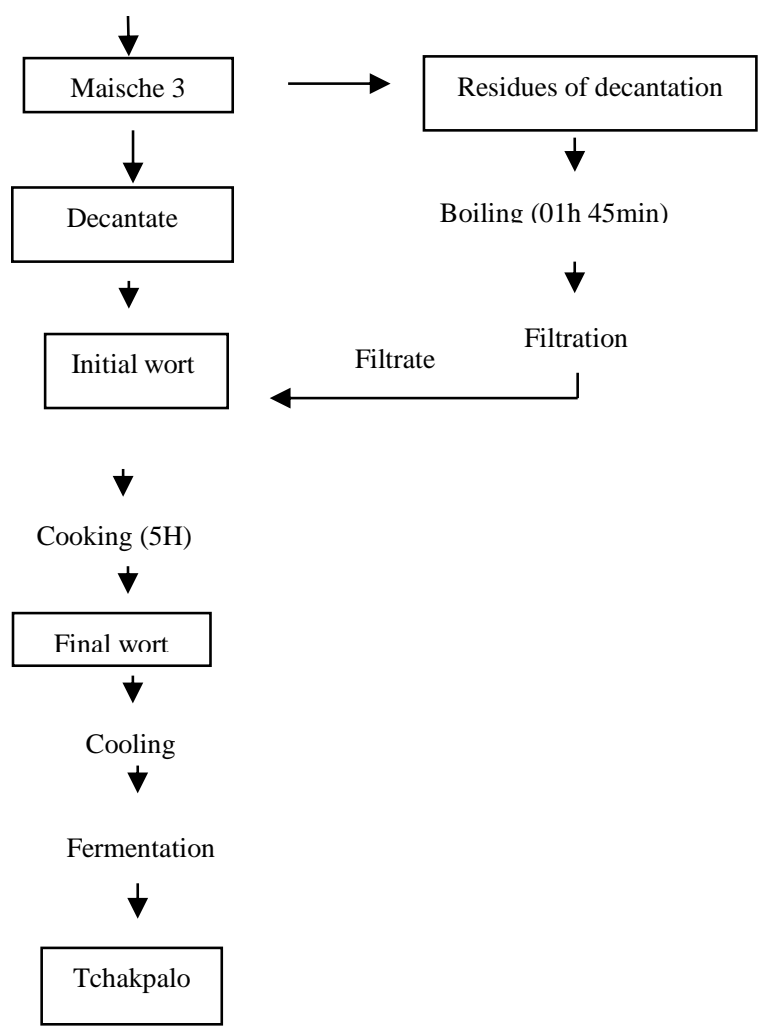

Figure1 Manufacturing process of Tchakpalo (Konfo et al 2014)

\section{FERMENTATION AND IMPROVEMENT OF AFRICAN TRADITIONAL SORGHUM BEERS}

Characteristics of African traditional beers brewed with sorghum malt have been reviewed by Lyumugabe et al. (2012). Fermentation is the important step by which yeast converts the sugars in the wort into ethyl alcohol. African traditional leaven is a result of the spontaneous fermentation of sorghum malt wort (Kayodé et al., 2005; Lyumugabe et al., 2010). Very varied yeasts and bacteria flora have been found in African sorghum beers, although $S$. cerevisiae and Lactobacillus sp. usually predominate (Novellie, 1976; Maoura et al., 2005; Kayodé et al., 2007b; Lyumugabe et al., 2010). Unlike European beer made with barley,
African sorghum beers are typical examples of lactic fermentation followed by alcoholic fermentation in which initially, lactic acid bacteria (LAB), and later yeasts, play the dominant role (Novellie 1982; Holzapfel, 1997; Kayodé et al., 2005; Maoura et al., 2009). Due to their higher growth rate, bacteria typically dominate the early stages of fermentation. A symbiotic relationship could explain the simultaneous presence of yeasts and LAB. LAB creates an acid environment favorable to the proliferation of yeasts. These yeasts produce vitamins and increase other factors, such as amino acids, to aid the growth of LAB. Table 2 shows characteristics of some African traditional sorghum beers and improvement suggested stages for their production.

\section{SHELF LIFE OF TRADITIONAL SORGHUM BEERS}

Most traditional, African cereal-based fermented foods deteriorate rapidly and become unacceptable to consumers within one to four days of production. The deleterious changes are primarily due to the objectionable off-flavour or oversouring induced by continued microbial activities after production (Kutyauripo et al., 2009). Traditionally-made sorghum beers have a poor keeping quality. The limited shelf life (stability) of sorghum beers has been reported as the major problem confronting commercial brewers in Sudan (Dirar 1978), in Tanzania (Tisekwa, 1989), in Nigeria (Sanni et al., 1999) in Rwanda (Lyumugabe et al., 2010) and in Benin (Konfo et al., 2012). Sorghum beer is consumed while it is still fermenting. The wort from which beer is made is not heated - or otherwise treated prior to the addition of yeast, and the drink therefore always carries a residual microflora originating mainly from its ingredients. Microorganisms such as Staphylococcus aureus, Esherichia coli, Bacillus subtilis, Streptococcus species, Proteus species, Rhizopus stolonifer, Aspergillus flavus, Aspergillus niger, Saccharomyce cerevisiae and Mucor species were also isolated from the samples. They explained that the presence of some these microorganisms in the samples may be attributed to poor handling during production. Some strains of E. coli can cause gastroenteritis and urinary tract infection as well as diarrhea in infant (Kolawolé et $\boldsymbol{a l . , 2 0 0 7 ) . ~ S o r g h u m ~ b e e r s ~ s p o i l ~ r a p i d l y ~ b e c a u s e ~ t h e y ~ a r e ~}$ actively fermenting when solid, with organisms in addition to yeasts flourishing in the rich medium. During fermentation, yeasts initially increase in number. Then in the later stage of logarithmic growth the production of ethanol starts and proceeds during the stationary phase. According to Baba-Moussa et al. (2012) the manufacturing process of tchakpalo, the environment and the way of selling are responsible of tchakpalo contamination. These authors added that it might be important to confirm these results, by studying microbiological quality of raw materials used for its preparation before their utilization. It has been observed that during storage, very little or no increase in the number of contaminating organisms seems to occur. However, at the end of fermentation, the yeasts die, or else they undergo autolysis and their cell constituents are released into the beer. With little or no competition from yeasts for the readily available nutrients, contaminating microorganisms increase rapidly in number and their metabolites change the flavor of the beer. Because of the relatively high temperature of fermentation, these sequential events occur within a short time period. This period does not usually exceed more than 3 days in summer or 5 days in winter before this spoilage occurs. The metabolic activities of mesophilic lactic acid bacteria are primarily responsible for the spoilage. These bacteria, along with other undesirable bacteria (Acetobacter), produce acetic acid, volatile off-flavors, fruity odors, and pellicles which render the taste, odor and texture of the beer unacceptable to consumers (Lyumugabe et $\boldsymbol{a l}$., 2012). The flash-pasteurization method increases the shelf life of industrial European beers by destroying spoilage microbes. Unfortunately, this process is not applied in traditional sorghum beer-making. Early attempts at pasteurization failed because they led to an unacceptable increase in beer viscosity through further gelatinization of starch and elimination of amylolytic enzymes and also eliminated the beer's characteristic effervescence by killing the active yeasts (Novellie $\boldsymbol{e t}$ al., 1986). On the other hand, pasteurization of beer results in the killing of a large proportion of yeast cells, thereby making the B-group vitamins they contain available to human consumers of beer (Van Heerden, 1987). Post-fermentation pasteurization has enabled the shelf life of "tugela gold" sorghum beer to be extended to an extent comparable to that of European barley beers (Haggblade $\boldsymbol{e t}$ al., 2004). The results obtained by Dossou et al. (2011) shown that the tchakpalo fermented by commercial yeast and the traditional ferment and stabilized by pasteurization at $60{ }^{\circ} \mathrm{C}$ during one hour can be preserved during at least 30 days at ambient temperature. However, the rear slightly bitter taste appeared in the tchakpalo fermented by commercial yeast and disapproved by tasters should be eliminated before all tentative of the technology transfer in real environment. Recently, Konfo et al. (2012) put in evidence the conservative power of essential oil (EO) of Cymbopogon citratus essential oil harvested for the preservation of the traditional beer tchakpalo, a local drink based on sorghum in Benin. Konfo et al. (2014) have shown that the aqueous extract of Hemizygia bracteosa (Benth) contains chemical natural compounds that give it its antifungal properties. The addition of this powder during the mashing found that it has a beneficial effect on the physico-chemical and microbiological parameters and gives a slightly sweet drink less acidic, with a low degree of alcohol. The table 3, figures 1 and figure 2 show results of microbiological and physico-chemical changes in sorghum beer during storage. 
Table 2 Characteristics of some African traditional sorghum beers

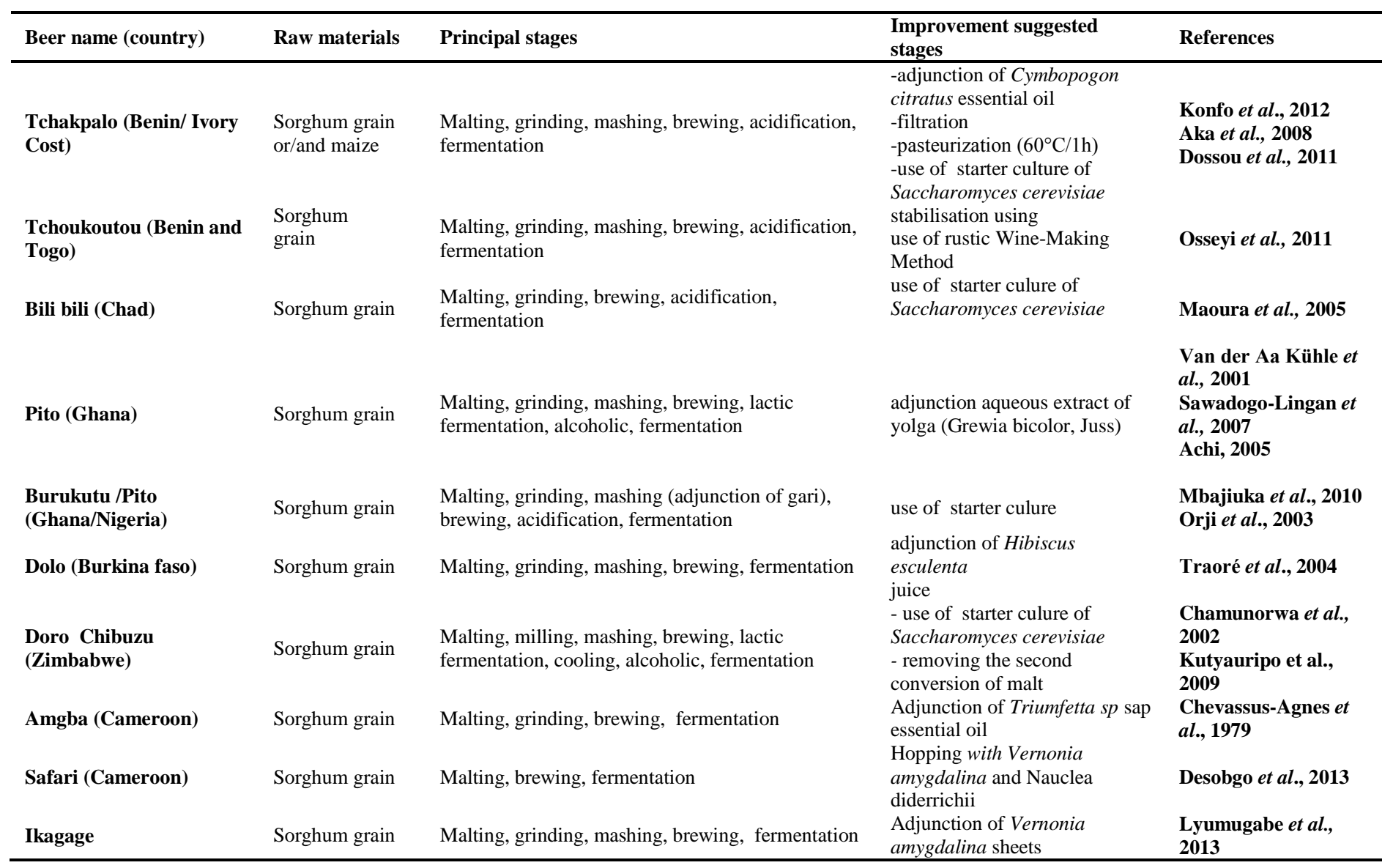

Table 3. Tchakpalo microbiological characteristics during storage (Konfo, 2012)

\begin{tabular}{|c|c|c|c|c|}
\hline $\begin{array}{l}\text { Microorganisms } \\
\text { Localities }\end{array}$ & & $\begin{array}{l}\text { esophilic } \\
\text { obic } \\
\text { (CFU/ml) }\end{array}$ & Yeasts (UFC/ml) & Moulds (CFU/ml) \\
\hline \multirow[t]{3}{*}{ Glazoue (center of Benin) } & D1 & $5610^{2}$ & $2.210^{2}$ & 80 \\
\hline & D5 & $510^{7}$ & $610^{6}$ & $1.210^{2}$ \\
\hline & D10 & $810^{12}$ & $910^{11}$ & $1.910^{4}$ \\
\hline \multirow{3}{*}{ Dassa (center of Benin) } & D1 & $8410^{2}$ & $4.110^{2}$ & $<1$ \\
\hline & D5 & $810^{7}$ & $710^{7}$ & 02 \\
\hline & D10 & $2.2210^{13}$ & $1.2010^{12}$ & 06 \\
\hline \multirow{3}{*}{ Cotonou (South of Benin) } & D 1 & $17.210^{2}$ & $3210^{2}$ & $<1$ \\
\hline & D5 & $2.510^{7}$ & $510^{6}$ & 01 \\
\hline & D10 & $5.810^{12}$ & $3.210^{11}$ & 04 \\
\hline (WHO) Criteria & \multicolumn{2}{|c|}{$\leq 10^{6}$} & $\leq 10^{4}$ & $\leq 10^{4}$ \\
\hline
\end{tabular}

D- Day

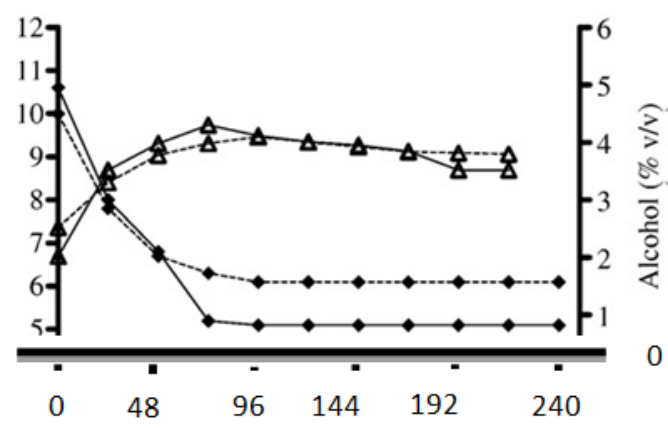

Time (hours)

Figure 2 Changes in total dissolved solids and alcohol concentration during fermentation of Chibuku beers. $-\Delta-$ alcohol control, $--\Delta-$ - alcohol variant, $-\bullet$ dissolved solids control, - - - - dissolved solids variant.

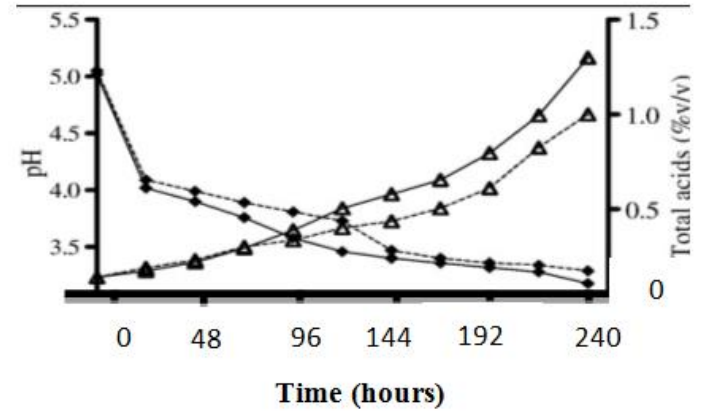

Figure 3 Changes in $\mathrm{pH}$ and total acids during fermentation of Chibuku beers. - $\mathrm{pH}$ control, - - - - $\mathrm{pH}$ variant, $-\Delta-$ total acids control, - - $\Delta-$ - total acids variant. 


\section{POTENTIAL APPLICATIONS OF PLANTS EXTRACTS AS NATURAL SORGHUM BEERS PRESERVATIVES.}

\section{ESSENTIAL OILS EXTRACTION AND CHEMICAL ANALYSIS}

EOs are products, generally, of rather complex composition comprising the volatile principles contained in the plants, and more or less modified during the preparation process. They are essentially obtained by hydrodistillation where the plant material is heated in two to three times its weight of water with indirect steam from outside the still. Chemical analysis of EOs is generally using GC (quantitative analysis) and GC/MS (qualitative analysis). Identification of the main components is carried out by the comparison of both the GC retention times and MS data against those of the reference standards (with known source) (Sessou et al., 2012).

\section{MECHANISM OF ANTIMICROBIAL ACTION OF EXTRACTS}

\section{ANTIFUNGAL ACTION}

Antifungal agents such as essential oils kill the fungal cell via binding primarily to ergosterol, the major sterol found in fungal cellular membrane. This binding destroys the osmotic integrity of the membrane, and this is followed by leakage of intracellular potassium, magnesium, sugars, and metabolites and finally by cellular death. Lipid characteristics of essential oils act via the same mechanism. It has been suggested that oxidative damage due to essential oil may also contribute to its antifungal activity against Candida (Murray et al., 2003).

\section{ANTIBACTERIAL ACTION}

The mechanisms of plants extracts compounds action and their effects on cellular membrane and cell wall are known. Their influence on the cell permeability, interfering on the membranous and cytoplasmic functions (electron flow, nucleic acids synthesis, protein synthesis coagulation of cell contents activity on proton motive force and on ATP production) could be at the origin of this antimicrobial character (Yehouenou et al., 2010b).

\section{ANTIMICROBIAL ACTIVITY OF PLANTS EXTRACTS IN FOODSYSTEMS.}

Spices and herbs can be used as an alternative preservative and pathogen-control method in food materials. Indeed, according to studies of Burt (2004), Dahouenon-Ahoussi et al. (2010), EO of Mentha piperita had been recognized as bio preservatives for Africa drink low-fat yoghurt (dairy products), fish dishes and vegetables. The same report was for essential oils of clove and cinnamon on vegetable and dairy products. The main active essential oil was clove oil (Burt, 2004). According to Ranasinghe et al. (2002), cinnamon and clove EOs could be used as antifungal agents to manage post fungal diseases of banana. Xylopia aethiopica fruit had a great potential to control Sitophilus zeamais, and therefore it could be used in the protection of maize grain from storage pest. Pesticida properties of Xylopia aethiopica seem to be related to $\beta$-pinene and terpinene-4ol concentrations (Kouninki et al., 2007). Lemongrass essential oil had potentia to preserve food such as rice, vegetable (Burt 2004).

Table 5 Major components, susceptible microorganisms and food preserved of selective essential oils.

\begin{tabular}{|c|c|c|c|c|c|}
\hline Plants & Countries & $\begin{array}{c}\text { Major } \\
\text { components }\end{array}$ & EO active agains & $\begin{array}{c}\text { Potential } \\
\text { biopreservative } \\
\text { of }\end{array}$ & References \\
\hline \multirow{3}{*}{$\begin{array}{l}\text { Cymbopogon } \\
\text { citratus }\end{array}$} & Benin & $\begin{array}{l}\text { Myrcene }(10.4) \\
\text { Neral }(33,0) \\
\text { Geranial }(41.3)\end{array}$ & $\begin{array}{l}\text { Escherichia coli ATCC } \\
25922 \\
\text { Staphylococcus aureus ATCC } \\
25923 \\
\text { Aspergillus niger } \\
\text { Fusarium oxysporum } \\
\text { Penicillium camembertii }\end{array}$ & Tchakpalo & Konfo et al., (2012) \\
\hline & Togo & $\begin{array}{l}\text { Neral }(31.36 \%) \\
\text { Geranial }(43.15) \\
\text { Myrcene } \\
(10.65 \%)\end{array}$ & $\begin{array}{l}\text { Candida albicans } \\
\text { Cryptococcus neoformans } \\
\text { Malassezia pachydermatis } \\
\text { Aspergillus fumigatus } \\
\text { Pseudomonas aeruginosa V5667 } \\
\text { Staphylococcus intermedius } \\
\text { IP81.60 }\end{array}$ & - & Koba et al., (2003) \\
\hline & Cameroon & $\begin{array}{l}\text { E- } \\
\text { Citral/Geranial } \\
\quad(37.7) \\
\\
\text { Z-Citral/Neral } \\
\quad(21.2-80)\end{array}$ & $\begin{array}{l}\text { Penicillium expansum, } P . \\
\text { verrucosum, A. ochraceus, } A . \\
\text { flavus, } L . \text { monocytogenes, } \\
\text { Salmonella }\end{array}$ & $\begin{array}{c}\text { fruits and } \\
\text { vegetables, rice }\end{array}$ & $\begin{array}{l}\text { Burt, (2004); Nguefack et al. } \\
(2009) \text {; Nguefack et al., } \\
(2004), \text { Nguefack et al., } \\
(2012) \text {. }\end{array}$ \\
\hline \multirow{3}{*}{ Mentha spica } & India & - & Aspergillus fumigatus ; A. niger & - & Bansod and Rai, (2008) \\
\hline & India & & Aspergillus fumigatus ; A. niger & - & Bansod and Rai, (2008) \\
\hline & Serbia & $\begin{array}{l}\text { Carvone (49.5) } \\
\text { Menthone (21.9) }\end{array}$ & $\begin{array}{l}\text { Aspergillus niger, Aspergillus } \\
\text { ochraceus, Aspergillus flavus, } \\
\text { Fusarium tricinctum, Penicillium } \\
\text { funiculosum }\end{array}$ & - & Sokovic et al., (2009) \\
\hline $\begin{array}{l}\text { Hemizygia } \\
\text { bracteosa }\end{array}$ & Bénin & $\begin{array}{l}\text { Tanins } \\
\text { Tanins } \\
\text { cathéchiques } \\
\text { Flavonoïdes } \\
\text { Anthocyanes }\end{array}$ & $\begin{array}{l}\text { Penicillium citrinum; Penicillium } \\
\text { italicum,; Aspergillus oryzae }\end{array}$ & tchakpalo & Konfo et al., (2014) \\
\hline
\end{tabular}

\section{FUTURE PERSPECTIVES}

To improve and control the production process and particularly the step of fermentation, the starter cultures are increasingly used. However, most of these starter cultures were introduced during the fermentation in the form of fresh microbial suspensions difficult to maintain over extended periods. To solve this problem, the use of dried starter cultures (lyophilization, spray drying, fluid bed drying), active and stable during storage, could be a viable and sustainable solution (Coulibaly et al., 2014). The use of plants extracts coupled by pasteurization could however constituted an effective alternative to the synthesis antifungal chemical compounds that are sometimes harmful to consumers' health and the environment. The most interesting area of application for extracts is the inhibition of growth and reduction in numbers of the more serious food borne pathogens such as fungi and bacteria strains (Salmonella spp, E. coli O157:H7 and L. monocytogenes). However, international standardization of the composition of commercially available extracts would be essential for reliable applications (Carson and Riley, 2001). Interactions between extracts and their components and other food ingredients and food additives need to be investigated. Clove and oregano oils can acquire a dark pigmentation when in contact with iron (Bauer et al., 2001); this may impose limitations on their application. Synergistic effects could be exploited so as to maximize the antimicrobial activities. The stability of extracts during food processing will also 
need to be studied. The heat stability of cinnamaldehyde has been investigated; it was found to decompose to benzaldehyde at temperatures approaching $60{ }^{\circ} \mathrm{C}$ when heated alone. When combined with eugenol or cinnamon leaf oil, however, cinnamaldehyde was stable even after $30 \mathrm{~min}$ at $200^{\circ} \mathrm{C}$ (Friedman et al., 2000).

\section{CONCLUSION}

Traditional sorghum beers have a socio-cultural and nutritional value in Africa The presence of unspecified microorganisms from traditional leaven complicates the control of the fermentation process and yields products of variable quality. The use of starter cultures seems to be a good method to reduce organoleptic variations and to reduce the risk of contamination with pathogenic organisms. This approach would also increase the chances of preserving of traditiona sorghum beer, giving it a longer shelf life. The pasteurization of sorghum beer appears most promising for resolving the brewer's perennial principal problem of a shorter shelf life. This operation coupled to the application of plants extracts could be a potential alternative to synthetic preservatives for reasons that they have large spectrum activity against Gram negative bacteria, Gram positive bacteria and fungi which are known to be the main factor of beverages deterioration. Thus there is hope that the current work can quickly lead to practical applications that will open new opportunities for the sector of aromatic herbs and spices, while ensuring drinks conservation in respect of the environment.

\section{REFERENCES}

ACHI, O K. 2005. The potential for upgrading traditional fermented foods through biotechnology. African Journal of Biotechnology, 4, 375-380.

AHMED, S.B., MAHGOUB S.A., BABIKER BE. 1996. Changes in tannin and cyanide contents and diastic activity during germination and the effect of traditional processing on cyanide content of sorghum cultivar. Food Chemistry. 56, 159-162. http://dx.doi.org/10.1016/0308-8146(95)00157-3

AKA, S., N'GUESSAN, K., YAO, K.C., DJE, K. 2008. Variabilité des propriétés physico-chimiques et dénombrement de la flore fermentaire du tchapalo, une bière traditionnelle de sorgho en Côte d'Ivoire, Afrique Science, 4, 1-11.

ANGLANI, C. 1998. Sorghum for human food: a review. Plant Foods for Human Nutrition, 52(1), 85-89.

ANTUNES, M.D.C., CAVACO, A.M. 2010. The use of essential oils for postharvest decay control. A review. Flavour and Fragrance Journal, 25, 351366. http://dx.doi.org/10.1002/ffj.1986

BABA-MOUSSA, F., BANKOLE, S.H., ADEOTI, K., AHOUANDJNOU, H., GBENOU, J., TOUKOUROU, F., SEZAN, A., KOTCHONI, O. S., BABAMOUSSA, L. 2012. Study of microbiological quality of the fermented drink "Tchakpalo" consumed in Benin roads. International Research Journal of Microbiology, 3, 147-152.

BALlOGOU, V.Y., DOSSOU, J., DE SOUZA, C. A. 2011. Controlled Drying Effect on the Quality of Sorghum Malts Used for the Chakpalo Production in Benin. Food and Nutrition Sciences, 2, 156-161. http://dx.doi.org/10.4236/fns.2011.22022

BANSOD, S., RAI, M.. 2008. Antifungal Activity of Essential Oils from Indian Medicinal Plants against Human Pathogenic Aspergillus fumigatus and A. niger. World Journal of Medical Sciences 3, 81-88.

BAUER, K., GARBE, D., SURBURG, H. 2001. Common Fragrance and Flavor Materials: Preparation, Properties and Uses. 3rd edit. Wiley-VCH, Weinheim, 290p. ISBN 9783527612376

BRIGGS, D.E., HOUGH, J.S., STEVENS, R.., YOUNG, T.W. 1981. Malting and brewing science. Vol 1. London: Chapman \& Hall. Springer Science \& Business Media. 914p. ISBN 9780412165801

BURT, S. 2004. Essential oils: Their antibacterial properties and potential applications in foods-a review. International Journal of Food Microbiology 94, 223-253. http://dx.doi.org/doi:10.1016/j.ijfoodmicro.2004.03.022

CARSON, C.F., RILEY, T.V. 2001. Safety, efficacy and provenance of tea tree (Melaleuca alternifolia) oil. Contact Dermatitis, 45, 65- 67 http://dx.doi.org/10.1034/j.1600-0536.2001.045002065.x

CHAMUNORWA, A.T., FERESU, S.B., MUTUKUMIRA, A.N. 2002 Identification of lactic acid bacteria isolated from opaque beer (Chibuku) for potential use as a starter culture. The Journal of Food Technology in Africa 7, 9397. http://dx.doi.org/10.4314/jfta.v7i3.19239

CHEVASSUS-AGNES, S., FAVIER ,J.C., JOSEPH, A. 1979. Traditional technology and nutritive value of Cameroon sorghum beers. Cah. Onarest, 83 112.

COUliBALY, W.H., N'GUESSAN, K.F., COULIBALY, I., DJE K.M. THONART, P. 2014. Les levures et les bactéries lactiques impliquées dans les bières traditionnelles à base de sorgho produites en Afrique subsaharienne (synthèse bibliographique). Biotechnol. Agron. Soc. Environ. 18, 209-219.

DAHOUENON-AHOUSSI, E., SESSOU, P., WOTTO, D.V., YEHOUENOU, B., KINSOUDE, E., KPATINVOH, B., SOUMANOU, M., SOHOUNHLOUE, D. 2010. Mise au point d'une technologie de production d'une boisson locale Africa drink à base d'huiles essentielles de menthes verte et poivrée. Bulletin d'Information de la Société Ouest Africaine de Chimie 7, 39-53.
DE LAME, D. 1995. La bière en bouteille et le lait de la houe, parabole d'une colline rwandaise. In : DEVISCH, R., DE BOECK, F. \& JONCKERS, D., eds Alimentations, traditions et développements en Afrique intertropicale. Paris L'Harmattan, 116-153.

DE LAME, D. 1996. Une colline entre mille ou le calme avant la tempête: transformations et blocages du Rwanda rural. Annales sciences humaines, Vol 154. Tervuren, Belgique : Musée Royal de l'Afrique Centrale. Ed Koninklijk Museum voor Midden-Afrika. 358p.

DESOBGO, Z.S.C., NAPONNI, F. Y., NSO, J. E. 2013. Caractérisation des moûts et bières du sorgho Safrari houblonnés avec Vernonia amygdalina et Nauclea diderrichii. International Journal of Innovation and Applied Studies. 2, 83-91.

DEWAR, J., TAYLOR, J.R.N., OROVAN, E. 1997. Effect of alkaline steeping on water uptake and malt quality in sorghum. Journal of the Institute of Brewing 103, 283-285. http://dx.doi.org/10.1002/j.2050-0416.1997.tb00957.x

DICKO, M.H., GRUPPEN, H, TRAORE, A.S., VORAGEN, A.G.J., VAN BERKEL, W.J.H. 2006. Sorghum grain as human food in Africa: relevance of content of starch and amylase activities. African Journal of Biotechnology, 5, 384-395.

DIRAR, H.A. 1978. A microbiological study of Sudanese merissa brewing Journal of Food Science 43, 163-168. http://dx.doi.org/10.1111/j.13652621.1978.tb07388.x

DOSSOU, J., BALLOGOU. V., DE SOUZA, C., 2011. Etude comparative de la dynamique microbienne et la qualité du chakpalo fermente à la levure commerciale (saccharomyces cerevisiae) et au ferment traditionnel et stabilise par pasteurisation. Journal de la Recherche Scientifique de l'Université de Lomé (Togo) Série, A 13,39-51.

EZEOGU, L.I, OKOLO, B.N. 1995. Effects of air rest periods on malting sorghum response to final warm water steep. Journal of the Institute of Brewing, 101, 39-45. http://dx.doi.org/10.1002/j.2050-0416.1995.tb00848.x

FRIEDMAN, M., KOZUEKUE, N., HARDEN, L.A. 2000. Cinnamaldehyde content in foods determined by gas chromatography-mass spectrometry. Journal of Agricultural and Food Chemistry, 48, 5702-5709. http://dx.doi.org/10.1021/jf000585g

HAGGBLADE, S., HOLZAPFEL, H. 2004. Industrialization of Africa's indigenous beer brewing. In: Streinrous K.H. Industrialization of indigenous fermented foods. 2nd ed. New York, USA: CRC Press. 600p. ISBN 9780824750947.

HOLZAPFEL, W. 1997. Use of starter cultures in fermentation on a household scale. Food Control, 8, 241-258. http://dx.doi.org/10.1016/S09567135(97)00017-0

HOUNHOUIGAN, D.J. 1994. Fermentation of maise (Zean mays L.) meal for mawè production in Benin. Thesis Wageningen, ISBN 90-5485-207-0.

HUETZ DE LEMPS, A. 2001. Boissons et civilisations en Afrique. Pessac, France : Presses universitaires de Bordeaux. (Coll. « Grappes \& Millésimes »), 658 p. ISBN 2-86781-181-8

KAYODE, A.P.P., AEGBIDI, A., LINNEMENN, A.R., NOUT, M.J.R, HOUNHOUIGAN, J.D. 2005. Quality of farmer's varieties of sorghum and derived foods as perceived by consumers in Benin. Ecology of food and nutrition 44, 271-294. http://dx.doi.org/10.1080/03670240500187302

KAYODE, A.P.P., HOUNHOUIGANA, J.D., NOUT, M.J.R. 2007a. Impact of brewing process operations on phyta, phenolic compounds and in vitro solubility of iron and zinc in opaque sorghum beer. LWT - Food Science and Technology 40, 834-841. http://dx.doi.org/10.1016/j.lwt.2006.04.001

KAYODE, A.P.P., HOUNHOUIGANA, J.D., NOUT, M.J.R., NIEHOF, A. 2007b. Household production of sorghum beer in Benin: technological and socioeconomic aspects. The Journal of Food Technology in Africa 31, 258-264. http://dx.doi.org/10.1111/j.1470-6431.2006.00546.x

KOBA, K.S., RAYNAUD, C., MANDIN, D, MILLET, J., CHAUMONT, J.P. 2003. Activité antimicrobienne des huiles essentielles de Cymbopogon citratus L. (DC) Stapf., C. nardus L. Rendle et C. schoenanthus L. Spreng, Journal de Mycologie Médicale 13, 231-238.

KOLAWOLE, O. M., KAYODE, R. M .O., AKINDUYO, B. 2007. Proximate and microbial analyses of burukutu and pito produced in Ilorin, Nigeria. African Journal of. Biotechnology, 5, 587-590.

KONFO, C T. R., CHABI, N W., AGBADJIZO, J., DAHOUENON-AHOUSSI, E., SOUMANOU, M. M., SOHOUNHLOUE, C.K.D. 2014. Influence de la feuille de Hemizygia bracteosa (Benth) sur la qualité de la bière du sorgho « tchakpalo » produite au Bénin. International Journal of Innovation and Applied Studies, 7, 2. 453-463

KONFO, C. 2012. Stabilisation de la boisson locale «Tchakpalo» par adjonction d'Huiles essentielles extraites des feuilles de Cymbopogon citratus, de Crassocephalum rubens et de Lippia multiflora. Thèse de DEA en Biologie de développement. Université de Lomé, Togo 100p.

KONFO, C., DAHOUENON-AHOUSSI E., SESSOU, P., YEHOUENOU, B. DJENONTIN S., DE SOUZA, C., SOHOUNHLOUE, D. 2012. Stabilization of local drink "Tchakpalo" produced in Benin by addition of essential oil extracted from fresh leaves of Cymbopogoncitratus. International Research Journal of Biological Sciences 1, 40-49. 
KOUNINKI, H., HAUBRUGE, E., NOUDJOU, F.E., LOGNAY, G., MALAISSE, F., NGASSOUM, M.B., GOUDOUM. A., MAPONGMETSEM, P.M., NGAMO, L.S., HANCE, T. 2007. Toxicity of some terpenoids of essential oils of Xylopia aethiopica from. Cameroon against Sitophilus zeamais Motsch Journal of applied Entomology 131, 269-274. http://dx.doi.org/10.1111/j.14390418.2007.01154.X

KUMAR, L.S., DAUDU, M.A, SHETTY, H.S., MALLESHI, N.G. 1992. Seed mycoflora and malting characteristics of some sorghum cultivars. Journal of Cereal Science, 15, 203-209. http://dx.doi.org/10.1016/S0733-5210(09)80072-6 KUTYAURIPO, J., PARAWIRA, W., TINOFA, S., KUDITA, I., NDENGU, C. 2009. Investigation of shelf-life extension of sorghum beer (Chibuku) by removing the second conversion of malt. International Journal of Food Microbiology.

129 ,

$271-276$

http://dx.doi.org/10.1016/j.ijfoodmicro.2008.12.008

LYUMUGABE, F., BAJYANA, S.E, WATHEL, J. P., THONAR, P. 2013 Volatile compounds of the traditional sorghum beers "ikigage" brewed with Vernonia amygdalina "umubirizi" Cerevisia, 37, 89-96. http://dx.doi.org/10.1016/j.cervis.2012.12.001

LYUMUGABE, F., GROS, J., NZUNGIZE, J., BAJYANA, E., THONART, P 2012. Characteristics of African traditional beers brewed with sorghum malt: a review. Biotechnologie, Agronomie, Société et Environnement 16, 509-530. LYUMUGABE, L., KAMALIZA. G, BAJYANA, E., THONART, P.H. 2010 Microbiological and physico-chemical characteristics of Rwandese traditional beer "Ikigage". African Journal of Biotechnology 9, 4241-4246.

MAOURA, N., MBAIGUINAM, M., NGUYEN, H.V., GAILlARDIN, C., POURQUIE, J. 2005. Identification and typing of the yeast strains isolated from bili bili, a traditional sorghum beer of Chad. African Journal of Biotechnology 4, 646-656.

MAOURA, N., POURQUIE, J. 2009. Sorghum beer: production, nutritional value and impact upon human health. In: Preedy V.R., ed. Beer in health disease prevention. Burlington, MA, USA: Elsevier Academic Press, 53-60. ISBN 9780080920498

MBAJIUKA, C., OMEH, Y., EZEJA, M. 2010. Fermentation of sorghum using yeast (Saccharomyces cerevisiae) as a starter culture for burukutu production. Continental Journal Biological Sciences 3, 63-74.

MURRAY, R., PATRICK BARON, J.E., JORGENSEN. J.H., PFALLER, Y.RH 2003. Manual of Clinical Microbiology 8è Ed pp1859-1879.

NGUEFACK, J., BUDDE, B.B., JAKOBSEN, M. 2004. Five essential oils from aromatic plants of Cameroon: their antibacterial activity and ability to permeabilize the cytoplasmic membrane of Listeria innocua examined by flow cytometry. Letters in Applied Microbiology, 39, 395-400. http://dx.doi.org/10.1111/j.1472-765X.2004.01587.x

NGUEFACK, J., LEKAGNE D.J.B., DAKOLE, CD., LETH, V., VISMER, H.F., TORP, J., GUEMDJOM, E.F.N;, MBEFFO, M., TAMGUE, O., FOTIO, D. AMVAM, Z.PH., NKENGFACK, A.E. 2009. Food preservative potential of essential oils and fractions from Cymbopogon citratus, Ocimum gratissimum and Thymus vulgaris against mycotoxigenic fungi. International Journal of Food Science. 131, 151-156. http://dx.doi.org/10.1016/j.ijfoodmicro.2009.02.009 NGUEFACK. J., TAMGUE, O., LEKAGNE, J.B., DONGMO, C.D., DAKOLE, V., LETH H.F., VISMER, PH., ZOLLO, A., NKENGFACK, A.E. 2012 Synergistic action between fractions of essential oils from Cymbopogon citratus, Ocimum gratissimum and Thymus vulgaris against Penicillium expansum. Food Control, 23, 377-383. http://dx.doi.org/10.1016/j.foodcont.2011.08.002

NOUT, M.J.R., ROMBOUTS, F.M. 1992. Fermentative preservation of plan foods. Journal of Applied Bacteriology. Symposium Supplement 73, 136S-147S NOVELLIE, L. 1962. Kaffircorn malting and brewing studies XI. Effect of malting conditions on the diastatic power of kaffircorn malts. Journal of the Science of Food and Agriculture, 13, 115-120 http://dx.doi.org/10.1002/jsfa.2740130210

NOVELLIE, L. 1976. Beverages from sorghum and millets. In: Dendy D.A.V. ed. Proceedings of the International symposium on sorghum and millets for human food, 11-12th May 1976, 9th Congress of the International Association for Cereal Chemistry, Vienna. London: Tropical Products Institute, 73-77.

NOVELLIE, L. 1982. Fermented porridge. In: Proceedings of the International symposium on sorghum grain quality, 28-31 October 1981, Patancheru, India. Patancheru, India: ICRISAT 121-128.

NOVELLIE, L., DE SCHAEPDRIJVER, P. 1986. Modern developments in traditional African beers. Prog. Ind. Microbiol 23: 73-157.

OKAFOR, N., ANICHE, G.N. 1980. Brewing a lager beer from Nigerian sorghum. Brew. Distilling Int 10: 32-35

OKOLO, B.N., EZEOGU, L.I. 1996. Duration of final warm water steep as a crucial factor in protein modification in sorghum malts, Journal of the Institute of Brewing, 102, 167-177. http://dx.doi.org/10.1002/j.2050-0416.1996.tb00905.x. OKUNGBOWA, J., OBETA, J., EZEOGU, L.I. 2002. Sorghum b-amylase production: relationship with grain cultivar, steep regime, steep liquor composition and kilning temperature. Journal of the Institute of Brewing, 108 , 362-370. http://dx.doi.org/10.1002/j.2050-0416.2002.tb00562.x

ORJI, M.U., MBATA, T.I., ANICHE, G.N., AHONKHAI, I. 2003. The use of starter cultures to produce 'Pito', a Nigerian fermented alcoholic beverage. World
Journal Microbiology and Biotechnology. 19, 733-736. http://dx.doi.org/10.1023/A:1025172506965

OSSEYI, T.E., KAROU, S.., KETEVI, A., LAMBONI, R. 2011. Stabilization of the Traditional Sorghum Beer, "Tchoukoutou" using Rustic Wine-Making Method. Advance Journal of Food Science and Technology 3, 254-258.

RANASINGHE, L., JAYAWARDENA, B., ABEYWICKRAMA, K. 2002. Fungicidal activity of essential oils of Cinnamomum zeylanicum (L.) and Syzygium aromaticum (L.) Merr et L.M.Perry against crown rot and anthracnose pathogens isolated from banana. Letters in Applied Microbiology, 35, 208-211. http://dx.doi.org/10.1046/j.1472-765X.2002.01165.x

SANNI, A.I., ONILUDE, A.A., FADAHUSI, I.F., AFOLABI R.O. 1999. Microbial deterioration of traditional alcoholic beverages in Nigeria. Food Research International, 32, 163-167. http://dx.doi.org/10.1016/S09639969(99)00068-X

SAWADOGO-LINGANI, H., LEI, V., DIAWARA, B., NIELSEN, D.S . MØLLER, P.L., TRAORE, A.S., JAKOBSEN, M. 2007. The biodiversity of predominant lactic acid bacteria in dolo and pito wort for the production of sorghum beer. Journal of Applied Microbiology. 103, 765-777. http://dx.doi.org/10.1111/j.1365-2672.2007.03306.x

SESSOU, P., FAROUGOU, S., SOHOUNHLOUE, D. 2012. Major component and potential applications of plant essentials oils as natural food preservatives: a short review research results. International Journal of Biosciences 2, 45-57.

SOKOVIC, M.D., VUKOJEVIC. J., MARIN PD., BRKIC. D.D., VAJS, V., VAN GRIENSVEN, J.L.D. 2009. Chemical Composition of Essential Oils of Thymus and Mentha Species and Their Antifungal Activities. Molecules, 14, 238 249. http://dx.doi.org/10.3390/molecules 14010238

TATSADJIEU, N.L., DONGMO, P.M., NGASSOUM, MB., ETOA, FX. MBOFUNG, C.M.F. 2009. Investigations on the essential oil of Lippia rugosa from Cameroun for its potential use as antifungal agent against Aspergillus flavus $\begin{array}{lllll}\text { Link ex Fries. Food Control 20, 161-166. } & \end{array}$ http://dx.doi.org/10.1016/j.foodcont.2008.03.008.

TAUR, A.T., PAWAR, V.D., INGLE, U.M. 1984. Effect of fermentation on nutritional improvement of grain sorghum (Sorghum bicolor (L.) Moench). Indian Journal of Nutrition and Dietetic 21, 129-136.

TAYLOR, J., DEWAR, J. 2000. Fermented products: Beverages and porridges. In 'Sorghum: Origin, History, Technology, and Production' (C. Wayne Smith and R.A. Frederiksen, eds), John Wiley \& Sons, New York 751-795

TISEKWA, B. 1989. Improvement of traditional manufacturing of sorghum beer (mtama) in Tanzania. PhD thesis: Ghent University (Belgium)

TRAORE, T., MOUQUET, C., ICARD-VERNIERE, C., TRAORE, A.S. TRECHE, S. 2004. Changes in nutrient composition, phytate and cyanide contents and a-amylase activity during cereal malting in small production units in. Ouagadougou (Burkina Faso). Food Chemistry 88, 105-114. http://dx.doi.org/10.1016/j.foodchem.2004.01.032.

UVERE, P.O., ADENUGA, O.D., MORDI, C. 2000. The effect of germination and kilning on the cyanogenic potential, amylase and alcohol levels of sorghum malts used for burukutu production. Journal of Science, Food and Agriculture 80,352-358. http://dx.doi.org/10.1002/1097-0010(200002)80:3<352::AIDJSFA434>3.0.CO;2-I.

VAN DER AA KÜHLE, A., JESPEREN, L., GLOVER, R. L.K., DIAWARA, B. AND JAKOBSEN, M. 2001. Identification and characterization of Saccharomyces cerevisiae strains isolated from West African sorghum beer. Yeast 18, 1069-1079. http://dx.doi.org/10.1002/yea.756.

VAN HEERDEN, I.V., GLENNIE, G.W. 1987. Availability of B-vitamin in sorghum beer. Nutrition reports international, 35, 147-155.

YEHOUENOU, B., NOUDOGBESSI, J.P., SESSOU, P., AVLESSI, F., SOHOUNHLOUE, D. 2010a. Etude chimique et activités antimicrobiennes d'extraits volatils des feuilles et fruits de Xylopia aethiopica (DUNAL) A Richard contre les pathogènes des denrées alimentaires. Journal de la Société Ouest Africaine de Chimie, 29, 19-27.

YEHOUENOU, B., WOTTO, V., BANKOLE, L., SESSOU, P., NOUDOGBESSI, J.P., SOHOUNHLOUE, D. 2010b. Chemical study and antimicrobial activities of volatile extracts from fresh leaves of Crassocephalum rubens (Juss \& Jack) S. Moore against food-borne pathogens, Scientific Study \& Research, 11, 343-351. 